\title{
Pengaruh Kualitas Pelayanan Terhadap Kepuasan Pelanggan Pada PT. Ibrahim Abdullah Budi Mulia Cabang Pekanbaru
}

\author{
NEFRIDA \\ Sekolah Tinggi Ilmu Ekonomi Persada Bunda \\ Jl. Diponegoro No. 42 Pekanbaru \\ E-mail : nefrida.pb81@gmail.com
}

\begin{abstract}
This study aims to determine whether the quality of service consisting of tangible, empathy, reliability, responsiveness and assurance variables affect customer satisfaction. The population in this study were all customers. The sample was taken as many as 68 respondents using the Accidental sampling approach. Based on the results of the study, obtained multiple linear regression equation as follows $\mathrm{Y}=0.484+0.221 \mathrm{X} 1+0.108 \mathrm{X} 2+0.292 \mathrm{X} 3+0.207 \mathrm{X} 4$ $+0.146 \mathrm{X} 5+\mathrm{e}$. Validity and reliability test results stated that all statement items are valid and reliable. Based on the classic assumption test that is normality test, multicollinearity test and heteroscedasticity test, it is obtained the result that the data is normally distributed, there is no multicollinearity and the distribution of data points is not patterned. Tangible variable with regression coefficient 0.221 , reliability with coefficient 0.292 and responsiveness variables with regression coefficient 0.207 has a positive and partially significant effect on customer satisfaction. Emphaty variable with regression coefficient value 0.106 and assurance variable with regression coefficient value 0.146 there is no positive and significant effect on customer satisfaction. The variables tangible, empathy, reliability, responsiveness and assurance have a positive and significant effect simultaneously on customer satisfaction at PT Ibrahim Abdullah Budi Mulia Pekanbaru Branch
\end{abstract}

Keywords: Tangible, Empathy, Reliability, Responsiveness, Assurance and Customers Satisfaction

Era globalilasi saat ini,terdapat banyak perusahaan jasa bersaing untuk menjadi yang terbaik.Keberhasilan perusahaan dalam mencapai tujuan berhubungan erat dengan kemampuan untuk menjaga pelanggan selalu menggunakan jasa yang di tawarkan.PT Ibrahim Abdullah Budi Mulia Cabang Pekanbaru merupakan perusahaan yang bergerak dalam bidang jasa penyedia dan penempatan tenaga kerja sebagai asisten rumah tangga untuk daerah Kota Pekanbaru.Dalam usaha memenangkan persaingan, perusahaan dituntut untuk memperhatikan kepuasan pelanggan. Kepuasan merupakan tingkat perasaan dimana seseorang menyatakan hasil perbandingan atas kinerja produk jasa yang diterima dengan yang diharapkan. Semakin baik kualitas pelayanan yang di berikan maka pelanggan semakin puas dan sebaliknya semakin buruk kualitas pelayanan yang diberikan kepada pelanggan maka semakin tidak
puas.Puasatau tidaknya pelanggan terhadap kualitas pelayanan yang di berikan dapat diketahui melalui ada atau tidaknya komplen dari pelanggan, berikut dapat dilihat data perkembangan jumlah pelanggan yang diikuti dengan komplen pelanggan pada PT Ibrahim Abdullah Budi Mulia Cabang Pekanbaru selama lima Tahun:

Tabel 1. Jumlah pelanggan dan jumlah komplen pelanggan PT Ibrahim Abdullah Budi Mulia cabang Pekanbaru Tahun 2011-2015

\begin{tabular}{|c|c|c|c|}
\hline THN & $\begin{array}{c}\text { Jumlah } \\
\text { Pelanggan } \\
\text { (orang) }\end{array}$ & $\begin{array}{c}\text { Jumlah } \\
\text { keluhan } \\
\text { pelanggan } \\
\text { (orang) }\end{array}$ & Persentase \\
\hline 2012 & 170 & 24 & 14 \\
\hline 2013 & 220 & 26 & 11,8 \\
\hline 2014 & 215 & 22 & 10 \\
\hline 2015 & 213 & 15 & 7 \\
\hline 2016 & 213 & 10 & 5 \\
\hline
\end{tabular}

Sumber : PT Ibrahim Abdullah Budi Mulia Cabang Pekanbaru 
Berdasarkan tabel 1 diatas dapat dilihat terjadinya fluktuasi jumlah pelanggan yang diikuti dengan jumlah komplen terhadap kualitas pelayanan yang diberikan perusahaan. Komplen di sampaikan melalui via telepon maupun secara langsung. Adapun permasalahan yang menjadi penilaian pelanggan yaitu keterbatasan fasilitas ruang tunggu kantor, tidak siapnya karyawan dalam pelayanan antar jemput tenaga kerja saat cuti dan kerapian karyawan yang dinilai masih kurang

Kepuasan pelanggan menurut Kotler (2014:150) ialah Perasaan senang atau kecewa yang muncul setelah membandingkan kinerja (hasil) produk yang dipikirkan terhadap kinerja (atau hasil) yang diharapkan.Jika kinerja berada dibawah harapan, pelanggan tidak puas.Jika kinerja memenuhi harapan pelanggan puas.Jika kinerja melebihi harapan, pelanggan amat puas atau senang. Menurut Zeithaml dan Bitner (2000:75) definisi kepuasan adalah: Respon atau tanggapan konsumen mengenai pemenuhan kebutuhan. Kepuasan merupakan penilaian mengenai ciri atau keistimewaan produk atau jasa, atau produk itu sendiri, yang menyediakan tingkat kesenangan konsumen berkaitan dengan pemenuhan kebutuhan konsumsi konsumen.

Menurut Tjiptono (2010:24). Aliansyah, Hafasnuddin dan Shabari dalam Afrinda Khoirista, Edy Yulianto dan M Kholid Mawardi (2015:3) menerangkan bahwa kepuasan adalah faktor penentu kesuksesan dan kelangsungan bisnis, semakin banyak pelanggan setia yang dimiliki oleh sebuah perusahaan, maka perusahaan tersebut akan sukses dan bertahan lama. Menurut Parasuraman dalam Fandy Tjiptono berpendapat bahwa kepuasan pelanggan menimbulkan kualitas jasa, kepuasan pelanggan terhadap pengalaman jasa tertentu akan mengarah pada evaluasi atau sikap keseluruhan terhadap kualitas jasa sepanjang waktu.

Kepuasan Pelanggan merupakan suatu evaluasi purna beli, jika kepuasan pelanggan tercapai maka akan timbul loyalitas dari pelanggan, oleh karena itu kepuasan pelanggan merupakan hal yang penting bagi perusahaan. Pelanggan yang merasa puas akan suatu produk dari suatu merek, maka umumnya terjadi pelanggan akan terus menerus membeli dan menggunakannya. Kualitas pelayanan dan kepuasan pelanggan adalah elemen penting yang harus dipertanggung jawabkan demi meningkatkan tujuan perusahaan (Ismail dan Haron, 2006)

Dari defenisi diatas dapat disimpulkan bahwa kepuasan pelanggan yang ditinjau dari sisi pelanggan yaitu mengenai apa yang telah dirasakan pelanggan atas pelayanan yang telah diberikan dibandingkan dengan apa yang di inginkan. Pelanggan akan merasa puas bila keinginan pelanggan telah terpenuhi oleh perusahaan sesuai dengan yang diharapkan. Produk yang memiliki nilai tambah pelanggan akan menjadi lebih puas dan kemungkinan untuk kembali dan menjadi pelanggan dalam waktu lama akan sangat besar

Kepuasan Pelanggan merupakan suatu tindakan dimana kebutuhan, keinginan dan harapan dari pelanggan dapat terpenuhi yang akan mengakibatkan adanya pembelian ulang atau kesetiaan yang berlanjut dalam (band 1991) dalam Musanto (2004:123-136). Untuk mewujudkan dan mempertahankan kepuasan pelanggan, organisasi jasa harus melakukan empat hal. Pertama, mengidentifikasi siapa pelanggannya. Kedua, memahami tingkat harapan pelanggan atas kualitas. Ketiga, memahami strategi kualitas layanan pelanggan, dan Keempat, memahami siklus pengukuran dan umpan balik dari kepuasan pelanggan (Tjiptono, 2004: 129)

Menurut Hawkins dan lonney dikutip dalam Tjiptono (2014:101) atribut pembentuk kepuasanterdiri dari :

1. Kesesuaian harapan

Merupakan tingkat kesesuaian antara kinerja produk yang diharapkan 
oleh pelanggan dengan yang dirasakan oleh pelanggan meliputi:

a. Produk yang diperoleh sesuai atau melebihi dengan yang di harapkan

b. Pelayanan oleh karyawan yang diperoleh sesuai atau melebihi dengan yang diharapkan

c. Fasilitas penunjang yang didapat sesuai atau melebihi dengan yang di harapkan

2. Minat berkunjung kembali

Merupakan kesediaan pelanggan untuk berkunjung kembali atau melakukan pembelian ulang terhadap produk terkait, meliputi:

a. Berminat untuk berkunjung kembali karena pelayanan yang diberikan oleh karyawan memuaskan

b. Berminat untuk berkunjung kembali karena nilai dan manfaat yang di peroleh setelah mengkonsumsi produk

c. Berminat untuk kembali karena fasilitas penunjang yang disediakan memadai

3. Kesediaan merekomendasikan

Merupakan kesediaan pelanggan untuk merekomendasikan produk yang telah di rasakannya kepada teman atau keluarga meliputi:

a. Menyarankan teman atau kerabat untuk membeli produk yang ditawarkan karena pelayanan yang memuaskan

b. Menyarankan teman atau kerabat untuk membeli produk yang ditawarkan karena fasilitas penunjang yang disediakan memadai

c. Menyarankan teman atau kerabat untuk membeli produk yang ditawarkan karena nilai atau manfaat yang didapat setelah mengkonsumsi sebuah produk jasa

Menurut Kotler dalam Fandy Tjiptono (2011:315) ada beberapa metode yang dipergunakan setiap perusahaan untuk mengukur dan memantau kepuasan pelanggannya dan pelanggan pesaing. Kotler mengidentifikasikan empat metode untuk mengukur kepuasan pelanggan, antara lain :

1. Sistem Keluhan dan Saran

Suatu perusahaan yang

berorientasi pada pelanggan akan memberikan kesempatan yang luas pada para pelanggannya untuk menyampaikan saran dan keluhan, misalnya dengan menyediakan kotak saran, kartu komentar dan lain-lain. Informasi dari para pelanggan ini akan memberikan masukan dan ide-ide bagi perusahaan agar bereaksi dengan tanggap dan cepat dalam menghadapi masalah-masalah yang timbul. Sehingga perusahaan akan tahu apa yang dikeluhkan oleh para pelanggannya dan segera memperbaikinya. Metode ini berfokus pada identifikasi masalah dan juga pengumpulan saran-saran dari pelanggan-nya langsung.

2. Ghost Shopping (Mystery Shopping)

Salah satu cara memperoleh gambaran mengenai kepuasan pelanggan adalah dengan mempekerjakan beberapa orang ghost shopers untuk berperan atau berpura-pura sebagai pelanggan potensial. Sebagai pembeli potensial terhadap produk dari perusahaan dan juga dari produk pesaing.

Kemudian mereka akan melaporkan temuan temuannya mengenai kekuatan dan kelemahan dari produk perusahaan dan pesaing berdasarkan pengalaman mereka dalam pembelian produk- produk tersebut. Selain itu para ghost shopper juga bisa mengamati cara penanganan terhadap setiap keluhan yang ada, baik oleh perusahaan yang bersangkutan maupun dari pesaingnya.

\section{Lost Customer Analysis}

Perusahaan akan menghubungi para pelanggannya atau setidaknya mencari tahu pelanggannya yang telah berhenti membeli produk atau yang telah pindah pemasok, agar dapat memahami penyebab mengapa pelanggan tersebut berpindah ke tempat lain. Dengan adanya peningkatan customer lost rate, di mana peningkatan customer lost rate 
menunjukkan kegagalan perusahaan dalam memuskan pelanggannya

4. Survei Kepuasan Pelanggan

Sebagian besar riset kepuasan pelanggan dilakukan dengan menggunakan metode survei, baik survei melalui pos, telepon, e-mail, website, maupun wawancara langsung. Melalui survey perusahaan akan memperoleh tanggapan dan balikan secara langsung (feedback) dari pelanggan dan juga akan memberikan kesan positif terhadap para pelanggannya.

Menurut Fornel et al (dalam Tjiptono, 2005) terdapat tiga aspek penting dalam kerangka pengukuran kepuasan pelanggan, yaitu:

1. Kepuasan general atau keseluruhan

2. Konfirmasi harapan, yaitu tingkat kesesuaian antara kinerja produk

3. Dibandingkan dengan ekspektasi

4. Perbandingan dengan situasi ideal, yaitu kinerja produk dibandingkan dengan produk ideal menurut persepsi pelanggan

Kotler mengemukakan pelayanan atau service adalah setiap kegiatan atau manfaat yang ditawarkan oleh suatu pihak kepada pihak lain dan pada dasarnya tidak berwujud dan tidak pula berakibat kepemilikan sesuatu dan produksinya dapat atau tidak dapat dikaitkan dengan suatu produk fisik

Pelayanan adalah kegiatan pemberian jasa dari satu pihak kepada pihak lainnya. Pelayanan yang baik adalah pelayanan yang dilakukan secara ramah tamah, adil, cepat, tepat dan etika yang baik sehingga memenuhi kebutuhan dan kepuasan bagi yang menerimanya, (Hasibuan, 2005:152)

Kualitas adalah segala sesuatu yang mampu memenuhi keinginan atau kebutuhan pelanggan.Kualitas didefinisikan sebagai totalitas karakteistik suatu produk yang menunjang kemampuan produk untuk memuaskan kebutuhan yang ditetapkan. Kualitas sering diartikan sebagai kepuasan pelanggan (customer satisfaction) atau konfirmasi terhadap kebutuhan pelanggan persyaratan (Gasperz 2006:1)
Kualitas Pelayanan pada umumnya dipandang sebagai hasil keseluruhan sistem pelayanan yang diterima konsumen, dan pada prinsipnya bahwa kualitas pelayanan berfokus pada upaya pemenuhan kebutuhan dan keinginan pelanggan.

Alma dalam bukunya Manajemen Pemasaran dan Pemasaran Jasa (2004:284) mengungkapkan ada 5 (lima) faktor dominan dalam kualitas pelayanan jasa yaitu:

1. Berwujud (Tangible). Yaitu berupa penampilan fasilitas fisik, peralatan dan berbagai materi komunikasi yang baik, menarik, terawatt dan lancer.

2. Empati (Emphaty). Yaitu ketersediaan karyawan dan pengusaha untuk lebih peduli memberikan perhatian secara pribadi kepada langganannya.

3. Cepat tanggap (Resvonsiveness). Yaitu kemauan dari karyawan dan pengusaha untuk membantu pelanggan dan memberikan jasa dengan cepat serta mendengar dan mengatasi keluhan dari konsumen.

4. Keandalan (Reliability). Yaitu kemampuan untuk memberikan jasa sesuai dengan yang dijanjikan, terpercaya, akurat serta konsisten.

5. Jaminan (Assurance). Yaitu berupa kemampuan karyawan untuk menimbulkan keyakinan dan kepercayaan terhadap janji perusahaan yang telah dikemukakan kepada konsumen.

Menurut Fandy Tjiptono (2014 :

268) definisi "Kualitas pelayanan berfokus pada upaya pemenuhan kebutuhan dan keinginan konsumen serta ketepatan penyampaianya untuk mengimbangi harapan konsumen".

Sedangkan Menurut Wyock (dalam lovelock,1988) yang dikutip oleh Fandy Tjiptono (2014 : 268) "Kualitas pelayanan merupakan tingkat keunggulan (excellent) yang diharapkan dan pengendalian atas keunggulan tersebut untuk memenuhi kebutuhan konsumen" 
Menurut Pasuraman (dalam Setyorini, 2011) mengemukana bahwa dari sepuluh dimensi kualitas pelayanan, dapat dirangkum menjadi lima dimensi, yaitu 1) Tangible, atau bukti fisik yaitu kemampuan perusahaan dalam menunjukkan penampilan dan kemampuan sarana dan prasarana fisik perusahaan; 2) Reliability atau kehandalan yaitu kemampuan perusahaan untuk memberikan pelayanan sesuai yang dijanjikan secara akurat dan terpercaya; 3) Responsiveness, atau ketanggapan yaitu suatu kemampuan untuk membantu dan memberi pelayanan yang cepat dan tepat kepada pelanggan, dengan penyampaian informasi yang jelas; 4) Assuranceatau jaminan dan kepastian yaitu pengetahuan, kesopansantunan, dan kemampuan para pegawai perusahaan untuk menumbuhkan rasa percaya para pelanggankepada perusahaan; 5) Empathy, yaitu memberikan perhatian yang tulus dan bersifat individual atau pribadi yang diberikan kepada para pelanggan dengan berupa memahami keinginan Pelanggan.

\section{METODE}

Variabel dalam penelitian ini terdiri dari variabel dependentdan independent. Adapun variabel dependen atau variabel $\mathrm{Y}$ yaitu kepuasan pelanggan, sedangkan variabel independen atau variabel $\mathrm{X}$ yaitu kualitas pelayanan yang terdiri dari variabel $\mathrm{X} 1$ tangible, variabel X2 empathy, variabel $\mathrm{X} 3$ reliability, variabel $\mathrm{X} 4$ responsiveness dan variabel X5 assurance.

Objek dalam penelitian ini adalah pelanggan yang menggunakan jasa tenaga kerja asisten rumah tangga melalui PT Ibrahim Abdullah Budi Mulia Cabang Pekanbaru. Populasi dalam penelitian ini seluruh pelanggan PT Ibrahim Abdullah Budi Mulia Cabang Pekanbaru dengan mengambil sampel menggunakan rumus Slovin. Jumlah populasi 213 di bagi 1 ditambah 213 di kali dengan kuadrat kesalahan atau error sehingga jumlah sampel adalah 68 Responden Jumlah indikator variabel Kualitas Pelayanan sebanyak 15 item dan indikator variabel kepuasan pelanggan 3

Jurnal Daya Saing (Vol. 5, No. 1 Februari 2019) item. Teknik pengumpulan data dengan menyebarkan angket yang berisi daftar pernyataan berkaitan dengan variabel penelitian. Sumber data pada penelitian ini berdasarkan data primer yang diambil langsung melalui penyebaran angket yang dilakukan pada periode April hingga Juli Tahun 2017

Metode Analisis data menggunakan metode deskriptif kuantitatif. Data penelitian yang diambil dari angket yang disebarkan kepada responden. Pengolahan data menggunakan program SPSS (statistical product and service solutions ) versi 21. Penelitian menggunakan skala likert untuk mengukur variabel penelitian. Menurut Sanusi (2011:59) skala likert adalah skala yang didasarkan pada penjumlahan sikap responden dalam merespon pernyataan yang berkaitan dengan indikator-indikator suatu konsep atau variabel yang sedang diukur. Adapun skala likert yang digunakan dalam penelitian yaitu: Sangat Setuju (SS), Setuju (S), Cukup Setuju (SC), Tidak Setuju (TS) dan Sangat Tidak Setuju (STS)

\section{HASIL}

Persamaan regresi linear berganda di gunakan untuk melihat hubungan linear antara variabel bebas terhadap variabel terikat apakah memiliki hubungan positif atau negatif dari kedua variabel dan untuk memprediksi nilai dari variabel terikat apabila terdapat kenaikan atau penurunan dengan menyertakan bilangan konstanta yang telah ditentukan besarnya.

Dari pengolahan data dengan menggunakan program SPSS versi 21 dapat dilihat hasil analisi regresi linear berganda pada tabel 2 sebagai berikut:

Tabel 2. Hasil analisis regresi linear berganda

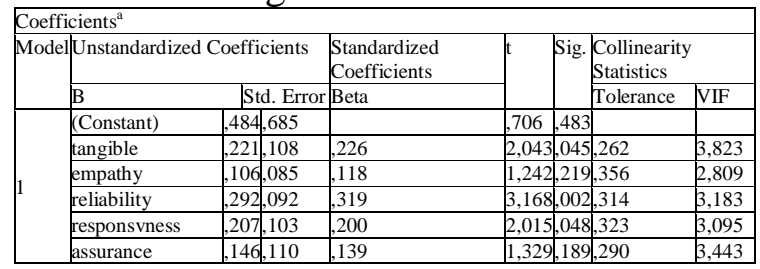

Sumber : pengolahan data SPSS

Dari tabel 2 hasil analisis regresi 
linear berganda tersebut diatas dapat di peroleh persamaan regresi linear berganda sebagai berikut:

$\mathrm{Y}=484+0,221 \mathrm{X} 1+0,108 \mathrm{X} 2+0,292 \mathrm{X} 3+0,207$

$\mathrm{X} 4+0,146 \mathrm{X} 5+\mathrm{e}$

Persamaan Regresi linear berganda dapat diinterpretasikan sebagai berikut:

a. Nilai konstanta adalah sebesar 484, artinya jika tangible, empathy, reliability, responsiveness dan assurance nilainya adalah 0 , maka kepuasan pelanggan $\mathrm{Y}$ nilainya adalah 484 satuan

b. Kepuasan pelanggan akan meningkat untuk setiap peningkatan tangible.

c. Kepuasan pelanggan akan meningkat untuk setiap peningkatan empathy

Kepuasan pelanggan akan meningkat untuk setiap peningkatan reliability

d. Kepuasan pelanggan akan meningkat untuk setiap peningkatan responsiveness

e. Kepuasan pelanggan akan meningkat untuk setiap peningkatan assurance

\section{Uji t (parsial)}

Untuk menguji keberartian model regresi untuk masing-masing variabel secara parsial dapat diperoleh dengan menggunakan uji t. Berikut akan dijelaskan pengujian masing-masing variabel secara parsial:

\section{a. Variabel Tangible}

Hasil pengujian diperoleh nilai $t$ untuk variabel tangible menunjukkan nilai t $=0,2043$ dengan nilai signifikansi $0,045<$ 0,05 . Dengan nilai signifikan dibawah 0,05 tersebut menunjukkan bahwa tangible memiliki pengaruh yang signifikansi terhadap kepuasan pelanggan. Hal ini berarti Hipotesis 1 di terima dan arah koefisien regresi positif berarti bahwa tangiblememiliki pengaruh positif yang signifikan terhadap kepuasan pelanggan. dimana semakin bertambah tangible maka kepuasan pelanggan akan bertambah, sebalik apabila berkurang pelayanan dari tangible maka kepuasan pelanggan juga berkurang.

b. Variabel Empathy

Hasil pengujian diperoleh nilai $t$ untuk variabel Empathy menunjukkan nilai $\mathrm{t}=0,1242$ dengan nilai signifikansi $0,29>$ 0,05 . Dengan nilai signifikan diatas 0,05 tersebut menunjukkan bahwa Empathy tidakmemiliki pengaruh yang signifikansi terhadap kepuasan pelanggan. Hal ini berarti Hipotesis 2 di tolak dan arah koefisien regresi negatif berarti bahwa empathy tidakmemiliki pengaruh yang signifikan terhadap kepuasan pelanggan.

c. Variabel Reliability

Hasil pengujian diperoleh nilai $\mathrm{t}$ untuk variabel reliability menunjukkan nilai $\mathrm{t}=0,3168$ dengan nilai signifikansi $0,002<$ 0,05 . Dengan nilai signifikan dibawah 0,05 tersebut menunjukkan bahwa reliabilitymemiliki pengaruh yang signifikansi terhadap kepuasan pelanggan. Hal ini berarti Hipotesis 3 di terima dan arah koefisien regresi positif berarti bahwa reliability memiliki pengaruh positif yang signifikan terhadap kepuasan pelanggan. dimana semakin bertambah reliability maka kepuasan pelanggan akan bertambah, sebalik apabila berkurang pelayanan darireliability maka kepuasan pelanggan juga berkurang.

\section{d. Variabel Responsiveness}

Hasil pengujian diperoleh nilai $\mathrm{t}$ untuk variabel responsiveness menunjukkan nilai $\mathrm{t}=0,2015$ dengan nilai signifikansi $0,048<0,05$. Dengan nilai signifikan dibawah 0,05 tersebut menunjukkan bahwa responsivenessmemiliki pengaruh yang signifikansi terhadap kepuasan pelanggan. Hal ini berarti Hipotesis 4 di terima dan arah koefisien regresi positif berarti bahwa responsivenessmemiliki pengaruh positif dan signifikan terhadap kepuasan pelanggan. dimana semakin bertambah responsiveness maka kepuasan pelanggan akan bertambah, sebalik apabila berkurang pelayanan dariresponsiveness maka kepuasan pelanggan juga berkurang.

\section{e. Variabel Assurance}

Hasil pengujian diperoleh nilai $\mathrm{t}$ untuk variabel Assurance menunjukkan nilai $\mathrm{t}=0,1329$ dengan nilai signifikansi $0,189>0,05$. Dengan nilai signifikan diatas 0,05 tersebut menunjukkan bahwa 
Assurance tidakmemiliki pengaruh yang signifikansi terhadap kepuasan pelanggan. Hal ini berarti Hipotesis 5 di tolak dan arah koefisien regresi negatif berarti bahwa Assurance tidakmemiliki pengaruh yang signifikan terhadap kepuasan pelanggan

\section{Uji F (simultan)}

Untuk menguji keberartian model regresi untuk masing-masing variabel secara simultan dapat diperoleh dengan menggunakan uji F. Pengujian masingmasing variabel secara simultan dapat di lihat pada tabel 12 sebagai berikut :

Tabel 3 Hasil Analisis Regresi linear berganda secara simultan

ANOVA $^{\mathrm{a}}$

\begin{tabular}{|l|l|l|l|l|l|}
\hline Model & $\begin{array}{l}\text { Sum of } \\
\text { Squares }\end{array}$ & $\begin{array}{l}\text { Mean } \\
\text { Square }\end{array}$ & F & Sig. \\
\hline Regression & 465,915 & 5 & 93,183 & 50,207 &, $000^{\text {b }}$ \\
\hline Residual & 115,071 & 62 & 1,856 & & \\
\hline Total & 580,985 & 67 & & & \\
\hline
\end{tabular}

a. Dependent Variable: kepuasan.plggn

b. Predictors: (Constant), assurance, empathy, responsvness, reliability, tangible

Sumber : pengolahan data SPSS versi 21.

Dari tabel 3 diatas dapat dilihat pengujian pengaruh variabel independen secara simultan terhadap variabel terikat dilakukan dengan menggunakan uji F. Hasil perhitungan statistic menunjukkan nilai $\mathrm{F}$ hitung $=50,207$ dengan nilai signifikansi $0,000<0,05$ dengan nilai signifikansi dibawah 0,05 dan menunjukkan bahwa kualitas pelayanan (tangible,empathy, reliability, responsiveness dan assurance) secara simultan mempunyai pengaruh yang positif dan signifikansi terhadap kepuasan pelanggan

Koefisien Determinasi $\left(R^{2}\right)$

Koefisien determinasi menunjukkan besarnya sumbangan secara efektif variabel independen terhadap variabel dependen. Koefisien determinasi bisa di lihat pada tabel 4 sebagai berikut:

Tabel 4. Koefisien Determinasi $\left(R^{2}\right)$ Model Summary ${ }^{\mathrm{b}}$

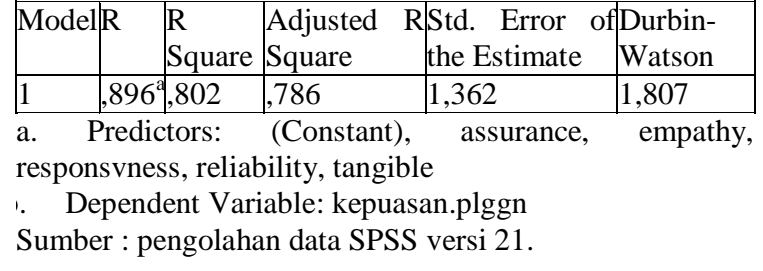

Dari tabel diatas dapat dilihat nilai koefisien determinasi (RSquare) sebesar 0,802 dengan demikian variasi kepuasan pelanggan yang dapat dijelaskan oleh variabel kualitas pelayanan (tangible,empathy, reliability, responsiveness dan assurance) adalah sebesar 80,2\% sedangkan sisanya $19.8 \%$ di jelaskan oleh faktor lain diluar variabel yang di teliti.

\section{PEMBAHASAN}

Pengaruh kualitas pelayanan terhadap kepuasan pelanggan pada PT Ibrahim Abdullah Budi Mulia Cabang Pekanbaru

Hasil pengujian hipotesis secara parsial, untuk melihat pengaruh masingmasing variabel independen terhadap variabel dependen, dalam hal ini yaitu variabel kualitas pelayanan yang terdiri dari tangible, empathy, reliability, responsiveness dan assurance. Hasil pengujian hipotesis 1 variabel tangible dengan indikator memiliki kantor yang nyaman, memiliki lapangan parkir yang memadai dan karyawan berpenampilan rapi menjadi perhatian penilaian yang perlu di pertimbangkan dan berpengaruh positif terhadap kepuasan pelanggan. Penilaian pelayanan secara fisik atau bukti nyata termasuk pada kategori sudah baik.Pelanggan merasa kenyamanan kantor penyedia tenaga kerja di rasa perlu, hal ini dapat di hubungan dengan kepercayaan pelanggan menggunakan jasa tenaga kerja asisten rumah tangga yang di salurkan.

Hasil pengujian hipotesis 2 variabel empathy dengan indikator memperhatikan kebutuhan pelanggan, karyawan yangmengutamakan kepentingan terbaik pelanggan dan karyawan sabar dalam melayani pelanggantidak memiliki pengaruh positif terhadap kepuasan pelanggan. Hal ini dikarenakan kebutuhan pelanggan akan jasa tenaga kerja asisten 
rumah tangga cukup tinggi, sehingga pelanggan kurang memperhatikan sikap karyawan yang kurang sabar dalam melayani, yang di butuhkan pelanggan tersedianya tenaga kerja asisten rumah tangga.

Hasil pengujian hipotesis 3 variabel reliability dengan indikator menyediakan jasa sesuai dengan yang dijanjikan, mampu mengatasi permasalahan pelanggan dan memberikan pelayanan yang baik dari awal sampai akhir berpengaruh positif dan signifikan terhadap kepuasan pelanggan. Pelanggan merasa perusahaan wajib memperhatikan kesesuaian kemampuan kerja asisten rumah tangga untuk membantu meringankan pekerjaan rumah pelanggan. Kemampuan karyawan dalam mengatasi permasalah dengan pelanggan dalam hal tenaga kerja asisten rumah tangga yang kurang mampu dalam bekerja, tidak cocok dengan pekerjaan ataupun tidak betah bekerja dan minta pindah tempat kerja. Hal ini membuat hubungan pelanggan dengan perusahaan kurang baik. Kondisi ini menuntut kecakapan karyawan dalam berkomunikasi dengan pelanggan.

Hasil pengujian hipotesis 4 variabel responsivenessdengan indikator memberikan pelayanan dengan tepat kepada pelanggan, memiliki kesediaan untuk membatu pelanggan dan memberikan kemudahan dalam proses pelayanan memberikan pengaruh yang positif dan signifikan terhadap kepuasan pelanggan. Pelanggan akan merasakan dekat dengan karyawan apabila menjelaskan manfaat dan nilai lebih terhadap produk jasa tenaga kerja asisten rumah tangga yang di tawarkan. Hal ini membuat pelanggan berfikiran positif dan percaya dengan karyawan yang dianggap memberikan penjelasan dengan baik.

Hasil pengujian hipotesis 5 variabel assurance dengan indikator membuat pelanggan merasa aman dalam bertransaksi, memberikan kemudahan dalam berkomunikasi dengan pelanggan dan selalu bersikap sopan kepada pelanggan tidak berpengaruh positif dan signifikan terhadap kepuasan pelanggan. Penilaian responden terhadap kualitas pelayanan pada variabel assurance sudah baik. Namun dalam menilai kepuasan pelanggan pada penelitian ini tidak berpengaruh. Hal ini karena peursahaan sudah memiliki standar pelayanan yang di dalamnya terdapat komunikasi dan sikap sopan karyawan.Penelitian ini sejalan dengan penelitian Januar Efendi \& Ai Lili Panjaitan (2016) Pengaruh kualitas pelayanan terhadap kepuasan pelanggan pada JNE Cabang Bandung, penelitian

\section{SIMPULAN}

Berdasarkan hasil dan pembahasan maka kesimpulan dalam penelitian ini adalah sebagai berikut:

1. Tangible memiliki pengaruh positif dan signifikan secara parsial terhadap kepuasan pelanggan pada PT Ibrahim Abdullah Budi Mulia Cabang Pekanbaru.

2. Variabel Empathy tidak memiliki pengaruh secara parsial terhadap kepuasan pelanggan pada PT Ibrahim Abdullah Budi Mulia Cabang Pekanbaru

3. Reliabilitymemiliki pengaruh positif dan signifikan secara parsial terhadap kepuasan pelanggan pada PT Ibrahim Abdullah Budi Mulia Cabang Pekanbaru

4. Responsibilitymemiliki pengaruh positif dan signifikan secara parsial terhadap kepuasan pelanggan pada PT Ibrahim Abdullah Budi Mulia Cabang Pekanbaru

5. Assurance tidak memiliki pengaruh secara parsial terhadap kepuasan pelanggan pada PT Ibrahim Abdullah Budi Mulia Cabang Pekanbaru

6. Kualitas pelayanan (tangible, empathy, reliability, responsiveness dan assurance) memiliki pengaruh positif dan signifikan secara simultan terhadap kepuasan pelanggan pada PT Ibrahim Abdullah Budi Mulia Cabang Pekanbaru

\section{DAFTAR RUJUKAN}


Anwar, Sanusi. 2011. Metodologi Penelitian Bisnis. Jakarta: Salemba Empat.

Buchari Alma, , 2004, Manajemen Pemasaran dan Pemasaran Jasa, Edisi Revisi, Bandung: Penerbit CV. Alfabeta.

Christoper Lovelock \& Lauren K Wright.2007. Manajemen Pemasaran Jasa, PT. Indeks, Indonesia

Fandy, Tjiptono, 2011, Pemasaran Jasa, Bayumedia, Malang.

,2005. Pemasaran Jasa. Malang: Bayumedia Publising.

Ghozali, Imam. 2012. Aplikasi Analisis Multivariate dengan Program IBM SPSS 20. Semarang: Badan Penerbit - Universitas Diponegoro.

Hartono Jogiyanto, 2004, Metodologi Penelitian Bisnis, Edisi 2004-2005, BPFE, Yogyakarta.

Hair, J.F., et al. (2010).Multivariate data analysis.(7th edition). New Jersey : Pearson Education Inc

Ismail, I., Haron, H., Ibrahim, D. N., and Isa, S. M. 2006. Service Quality Client

Ida Ayu Inten Surya Utami,2015.Pengaruh Kualitas Pelayanan terhadap Kepuasan Restoran Baruna Sanur Vol. 4 No.7,ISSN:2302-8912

Januar Efendi \& Ai Lili Yuliati Panjaitan,2016.Pengaruh Kualitas Pelayanan terhadap Kepuasan Pelanggan pada JNE Cabang Bandung. Vol. 11 No. 2

Satisfaction and LoyaltyToward Audit Firm: Perceptions of Malaysian Public listed Companies. Managerial Auditing Journal, 21(7), pp: 738756.
Kotler, Philip. \& Gary Armstrong.2014. Principle Of Marketing, 15th edition.

Khoirista,dkk. (2015) Pengaruh Kualitas Pelayanan terhadap Kepuasan Pelanggan. Vol. 25 No.2. Administrasi Bisnis New Jersey: Pearson Prentice Hall

2012. Prinsip-prinsipPemasaran Edisi 13. Jilid 1. Jakarta: Erlangga

Kotler, Phillip dan Kevin L. Keller, 2016, Marketing Management 16 edition. New Jersey: Pearson.

2012 Marketing Management 13 New

NI Made Arie Sulistyawati \& Niken Ketut Seminari, 2015, Pengaruh Kualitas Pelayanan Terhadap Kepuasan Pelanggan Restoran Indus Ubud Gianyar Vol. 4 No.8, 2015 ISSN:2318-2332 Jersey: Pearson Prentice Hall, Inc

2009. Manajemen Pemasaran. Jilid I. Edisi ke 13 Jakarta: Erlangga

Lupiyoadi, Rambat. 2014. Manajemen Pemasaran Jasa. Edisi 3. Jakarta: Salemba Empat.

2006. Manajemen Pemasaran Jasa. Edisi Kedua. Jakarta; Salemba Empat

Nilasari dan Istiatin, (2015) pengaruh Kualitas Pelayanan terhadap kepuasan Konsumen pada Diler PT Ramayana Motor Sukoharjo. Volume 13. No 1 Jurnal Paradigma

Nugroho (2014) Pengaruh Kualitas Pelayanan terhadap Kepuasan dan Loyalitas Pelanggan, Vol. 12 No.2 Jurnal Paradigma 